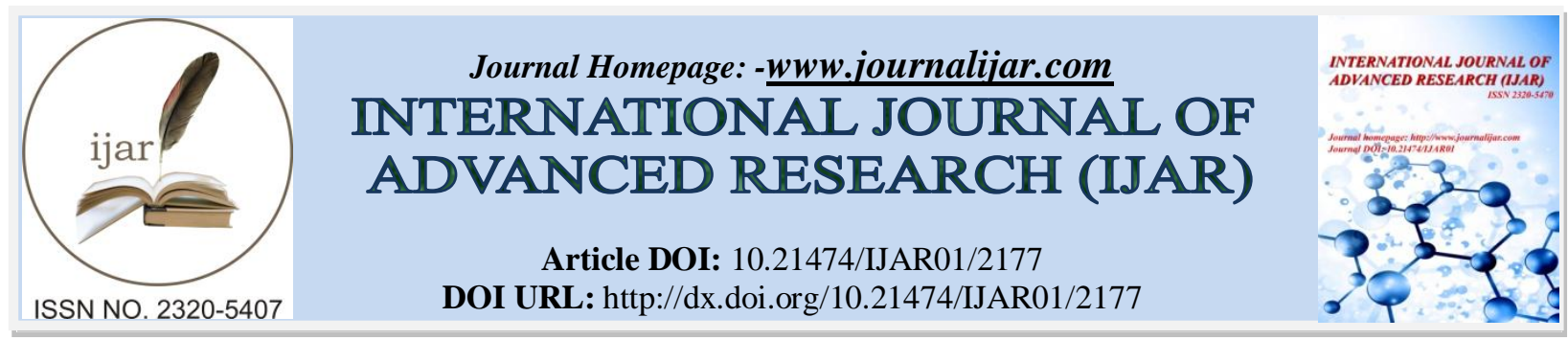

RESEARCH ARTICLE

\title{
STUDIES ON PHYTOPLANKTON RELATED DIVERSITY INDEX OF WESTERN RAMGANGA RIVER ALMORA UTTARAKHAND, INDIA.
}

\author{
Anupama Pandey. \\ Department of Zoology, R. H. Govt. P.G. College Kashipur, (U.K.) INDIA.
}

\section{Manuscript Info}

Manuscript History

Received: 26 September 2016

Final Accepted: 29 October 2016

Published: November 2016

Key words:-

Western Ramganga River, Diversity index, Phytoplankton, Community, Water quality.

\begin{abstract}
Spring fed Western Ramganga river is a hot spot of rich biological diversity. In the present study, the diversity of phytoplankton population and factors that control their growth and biodiversity were investigated. The numerical relationship between species population and communities often provide a better and reliable indication of the pollution than single species. Thus to assess water quality of Western Ramganga river, the phytoplankton densities were studied from one year of the study period (i.e. Jan., 2012 to Dec., 2012) at three sampling sites. In the present work 31 genera of phytoplankton belonging four classes were recorded. On the basis of observed phytoplankton densities, mean Shannon-Weiner diversity index of all three sites was computed. Diversity index is a most effective tool to communicate information on water quality. The mean value of the diversity index in present study indicates moderately polluted status of river water.
\end{abstract}

Copy Right, IJAR, 2016,. All rights reserved.

\section{Introduction:-}

Phytoplankton are ubiquitous and found in every type of water ecosystem, whether it is a stream, pond, lake or river. Phytoplankton plays an important role in the study of the floral biodiversity of aquatic ecosystems. Their community mainly comprises of members belonging to Chlorophyceae, Bacillariophyceae, Cyanophyceae and Dianophyceae (Welch, 1952). Phytoplankton community is very sensitive community and also the first target of water pollution, any undesirable change in river ecosystem influences the diversity and density of the community. Many researchers like Desai et al, (2008), Rajagopalet al, (2010), Vermaet al, (2013), Khan et al, (2013), Negi and Rajput, (2013) etc., have studied the phytoplankton communities in various aquatic bodies and reported different number of species in their studied water bodies. Although, the outcome of different studies is often controversial, alterations in species composition, density, biomass, community, etc. have been recorded in almost all cases. The habitats size of the river and climate of the area in which the water body is situated are most common factors that affect species number, diversity and richness.

In the present investigation, attempts have been made to assess the pollution level in the water of Western Ramganga River by computing Shannon-Weiner diversity index $\left(\mathrm{H}^{\prime}\right)$ on the basis of phytoplankton.

\section{Material And Methods:-}

The Western Ramganga River originated in the southern slopes of the Lesser Himalaya, Dudhatoli (3,110 amsl) ranges in the district of PauriGarhwal, Uttrakhand state of India. The river traverses near about $158 \mathrm{~km}$ before it 
meets the Kalagarh dam and continuous to downstream for about $322 \mathrm{~km}$ before joining river Ganga at Kannauj of Uttar Pradesh. The stretch of Western Ramganga River undertaken for the present work is about $45 \mathrm{~km}$ at three sampling sites, namely Gairsen, Chaukhutiya and Masi at Almora District of Uttarakhand. The study area, is located between $29^{\circ} 36^{\prime} \mathrm{N}$ latitude and $79^{\circ} 30^{\prime} \mathrm{E}$ longitude in the western part of central Himalaya.

For the quantitative estimations, known volume of surface water approximately 50 liters was filtered through the fine plankton net of $25 \mu \mathrm{m}$ mesh size and filtrate was collected in small collecting bottles. The volume of the filtrate was made up to $20 \mathrm{ml}$ and counting was done in a Sedgwick rafter cell. Identification was made with the help of books written by (Edmondson, 1959; Fitter and Manuel, 1986; APHA, 1999) etc.

Diversity index: The species diversity index of biotic communities was computed using Shannon-Wiener information function which is:

$$
\bar{H}=-\sum_{i=1}^{S} P i \log _{2} P i, \text { and }
$$

Concentration of dominance was calculated using Simpson's index as given below:

$$
\mathrm{C}=\sum_{i=1}^{s}(P i)^{2}
$$

Where $\mathrm{H}^{\prime}$ is the diversity index; $\mathrm{ln}$ is the natural logarithm; $\mathrm{i}$ is an index number for each species present in a sample; pi is the number of individuals within a species (ni) divided by the total number of individuals (N) present in the entire sample.

Data presentation and statistics-

To estimate monthly variations in plankton community, the average data of all sampling stations were used as replicates. That data finally used as monthly average value for computation of further observations.

\section{Results And Discussion:-}

During the entire study period i.e. Jan., 2012 to Dec., 2012, thirty-one phytoplankton taxa were collected in collection. Of these 31 species, maximum number (14) of species were contributed by the Chlorophyceae group. A similar observation was noticed in many other studies by the researchers in their representative water bodies $\{(\mathrm{e} . \mathrm{g}$. Devikaet al, 2006; Rajagopalet al, 2010 and Khan et al, 2013)\}. In addition, Essien- Ibok and Umoh, (2013) found dominancy of Bacillariophyceae over Chlorophyceae in their studied rivers. In terms of species composition Bacillariophyceae was the second dominant group. Cyanophyceae was third dominant group and the group Dianophyceae was represented by a single species. Phytoplankton community abundance varied from 78 units/l (Aug) to 908 (Apr) units/l with an annual average of 464 255 units/l (Table 1.1). The community abundance exhibited two peaks in the month of April and November. The peak of April was $86.44 \%$ greater than that of the second peak occurs in November. During the first peak, the group Chlorophyceae was dominant with the taxa Spirogyra sp., being the most abundant. During the second peak point of phytoplankton community abundance, the group Chlorophyceae again had maximum contribution with a single dominating species, Spirogyra. Being an extremely dominant group in terms of percentage share to the phytoplankton standing crop, the abundance of Chlorophyceae fluctuated from 18 units/l (Aug.) to 459 units/l (Apr.) Bacillariophyceae was the second dominant group and some species like Diatomasp. and Synedrasp. were almost perennial in occurrence while the rest of the constituting species of this group were intermittently present in the samples. The population size of this group varied from 60 units/l (Aug.) to 394 units/l (May). Cyanophyceae was the third dominant group the abundance of this group varied from 0 units/l to 58 units/l (Apr.). Being the least abundant group of phytoplankton community in the Western Ramganga River, the group Dianophyceae was present only in the month of October. During the entire study period, the group Chlorophyceae was dominant and contributed about $47 \%$ to the total phytoplankton number. Bacillariophyceae ranked second in terms of percentage share to the phytoplankton density and contributed about $46 \%$ part of the community. The group Cyanophyceae share about $7 \%$ of the total phytoplankton number. The group Dianophyceae shared least population $<1 \%$ to the total phytoplankton standing crop. Fig (1.1).

The Shannon-Weiner diversity index and Simpson's dominance index both are very significance function of the community. In the present research, the mean Shannon-Weiner diversity index of all three sampling sites ranged from 1.563 (Aug) to 3.039 (Mar). The concentration dominance showed an inverse relation to the species diversity 
index. During the entire study period of the present investigation, the mean dominance index of all three sampling sites ranged from 0.0531 (Nov) to 0.215 (Aug) Fig (1.2). Some data on diversity indices and the concentration of dominance of phytoplankton community of certain rivers are available for comparison. Shekharet al, (2008) estimated values of Shannon index for phytoplankton between 1.64 to 4.07 in Bhadra river (India), Panda, et al, (2011) computed Shannon weaver diversity index $(\mathrm{H})$, ranging between 0.22 and 2.49 in Dhamra river (India), Ramesha and Sophia, (2013) noted species diversity (H' log) ranged from 1.2889 to 2.7056 in Seeta river (India). In Western Ramganga diversity indices values are greater than 1 it indicates moderate quality of river water.

\section{Conclusion:-}

However, this study provides clear information about plankton diversity and species composition, which is the most important biological data for the assessment of river water quality. Moreover, present study emphasizes the necessity of using phytoplankton as an effective tool for bio-monitoring water quality of river Western Ramganga.

\section{Acknowledgement:-}

The author is thankful to her parents and Dr. Pramod Kumar Department of Zoology, R. H. G. P. G. C. KashipurUttarakhand for providing necessary help to carry out the work.

Table 1.1:-Quantitative analysis of Phytoplankton of Western RamGanga River Year-2012

\begin{tabular}{|c|c|c|c|c|c|c|c|c|c|c|c|c|}
\hline Phytoplankton & Jan & Feb & Mar & Apr & May & Jun & Jul & Aug & Sep & Oct & Nov & Dec \\
\hline \multicolumn{13}{|l|}{ Chlorophyceae- } \\
\hline Cladophora & 22 & 35 & 40 & 55 & 52 & 45 & 28 & 18 & 26 & 32 & 40 & 37 \\
\hline Closterium & 0 & 0 & 0 & 0 & 0 & 0 & 0 & 0 & 0 & 0 & 0 & 0 \\
\hline Desmidium & 0 & 0 & 0 & 0 & 0 & 0 & 0 & 0 & 0 & 0 & 0 & 0 \\
\hline Draparnaldiopsis & 10 & 14 & 18 & 22 & 28 & 12 & 0 & 0 & 14 & 20 & 23 & 20 \\
\hline Enteromorpha & 0 & 0 & 8 & 18 & 0 & 0 & 0 & 0 & 30 & 37 & 22 & 14 \\
\hline Hormidium & 8 & 15 & 18 & 20 & 15 & 11 & 5 & 0 & 9 & 12 & 5 & 4 \\
\hline Microspora & 0 & 16 & 27 & 31 & 18 & 0 & 0 & 0 & 15 & 27 & 0 & 0 \\
\hline Protococus & 0 & 0 & 10 & 25 & 18 & 5 & 2 & 0 & 4 & 6 & 8 & 4 \\
\hline Schizogonium & 0 & 17 & 27 & 36 & 0 & 0 & 0 & 0 & 0 & 18 & 24 & 18 \\
\hline Spirogyra & 55 & 67 & 92 & 106 & 95 & 0 & 0 & 0 & 0 & 0 & 28 & 36 \\
\hline Spirulina & 0 & 2 & 8 & 12 & 9 & 3 & 0 & 0 & 0 & 3 & 12 & 6 \\
\hline Tetraspora & 28 & 36 & 47 & 50 & 37 & 21 & 0 & 0 & 15 & 18 & 24 & 18 \\
\hline Ulothrix & 24 & 29 & 31 & 36 & 15 & 0 & 0 & 0 & 0 & 22 & 26 & 18 \\
\hline Zygnema & 31 & 37 & 42 & 48 & 52 & 37 & 10 & 0 & 0 & 14 & 30 & 38 \\
\hline Total Chlorophyceae & 178 & 268 & 368 & 459 & 339 & 134 & 45 & 18 & 113 & 209 & 242 & 213 \\
\hline \multicolumn{13}{|l|}{ Bacillariophyceae- } \\
\hline Amphora & 0 & 9 & 17 & 20 & 25 & 0 & 0 & 0 & 8 & 24 & 27 & 18 \\
\hline Ceratonies & 0 & 20 & 35 & 38 & 15 & 0 & 0 & 0 & 0 & 18 & 24 & 21 \\
\hline Cyclotella & 17 & 24 & 32 & 39 & 41 & 28 & 18 & 0 & 0 & 0 & 8 & 10 \\
\hline Cymbella & 0 & 42 & 48 & 53 & 57 & 60 & 0 & 7 & 0 & 0 & 0 & 0 \\
\hline Denticula & 0 & 0 & 17 & 20 & 14 & 8 & 0 & 0 & 9 & 16 & 20 & 0 \\
\hline Diatoma & 46 & 51 & 74 & 87 & 96 & 70 & 26 & 17 & 28 & 37 & 40 & 18 \\
\hline Fragillaria & 0 & 38 & 35 & 0 & 47 & 41 & 29 & 19 & 0 & 0 & 0 & 0 \\
\hline Gomphoneis & 0 & 0 & 0 & 0 & 0 & 0 & 29 & 0 & 0 & 0 & 0 & 0 \\
\hline Naviculla & 0 & 0 & 0 & 0 & 0 & 0 & 18 & 0 & 0 & 0 & 0 & 0 \\
\hline Neidium & 0 & 0 & 25 & 36 & 40 & 31 & 0 & 0 & 5 & 8 & 12 & 7 \\
\hline Nitzchia & 18 & 22 & 27 & 32 & 16 & 11 & 0 & 0 & 8 & 12 & 18 & 5 \\
\hline Pinnularia & 4 & 7 & 10 & 6 & 0 & 0 & 0 & 0 & 0 & 12 & 18 & 12 \\
\hline Synedra & 30 & 41 & 62 & 60 & 43 & 38 & 21 & 17 & 40 & 28 & 32 & 17 \\
\hline Total Bacillariophyceae & 115 & 254 & 382 & 391 & 394 & 287 & 141 & 60 & 98 & 155 & 199 & 108 \\
\hline \multicolumn{13}{|l|}{ Cyanophyceae- } \\
\hline Anabaena & 0 & 0 & 25 & 28 & 0 & 27 & 0 & 0 & 18 & 25 & 21 & 20 \\
\hline Oscillatoria & 0 & 22 & 0 & 0 & 0 & 17 & 0 & 0 & 0 & 26 & 0 & 0 \\
\hline Rivularia & 0 & 21 & 24 & 30 & 0 & 37 & 0 & 0 & 0 & 0 & 25 & 10 \\
\hline Total Cyanophyceae & 0 & 43 & 49 & 58 & 0 & 81 & 0 & 0 & 18 & 51 & 46 & 30 \\
\hline \multicolumn{13}{|l|}{ Dinophyceae- } \\
\hline Ceratium & 0 & 0 & 0 & 0 & 0 & 0 & 0 & 0 & 0 & 23 & 0 & 0 \\
\hline Total Phytoplankton & 293 & 565 & 799 & 908 & 733 & 502 & 186 & 78 & 229 & 438 & 487 & 351 \\
\hline
\end{tabular}




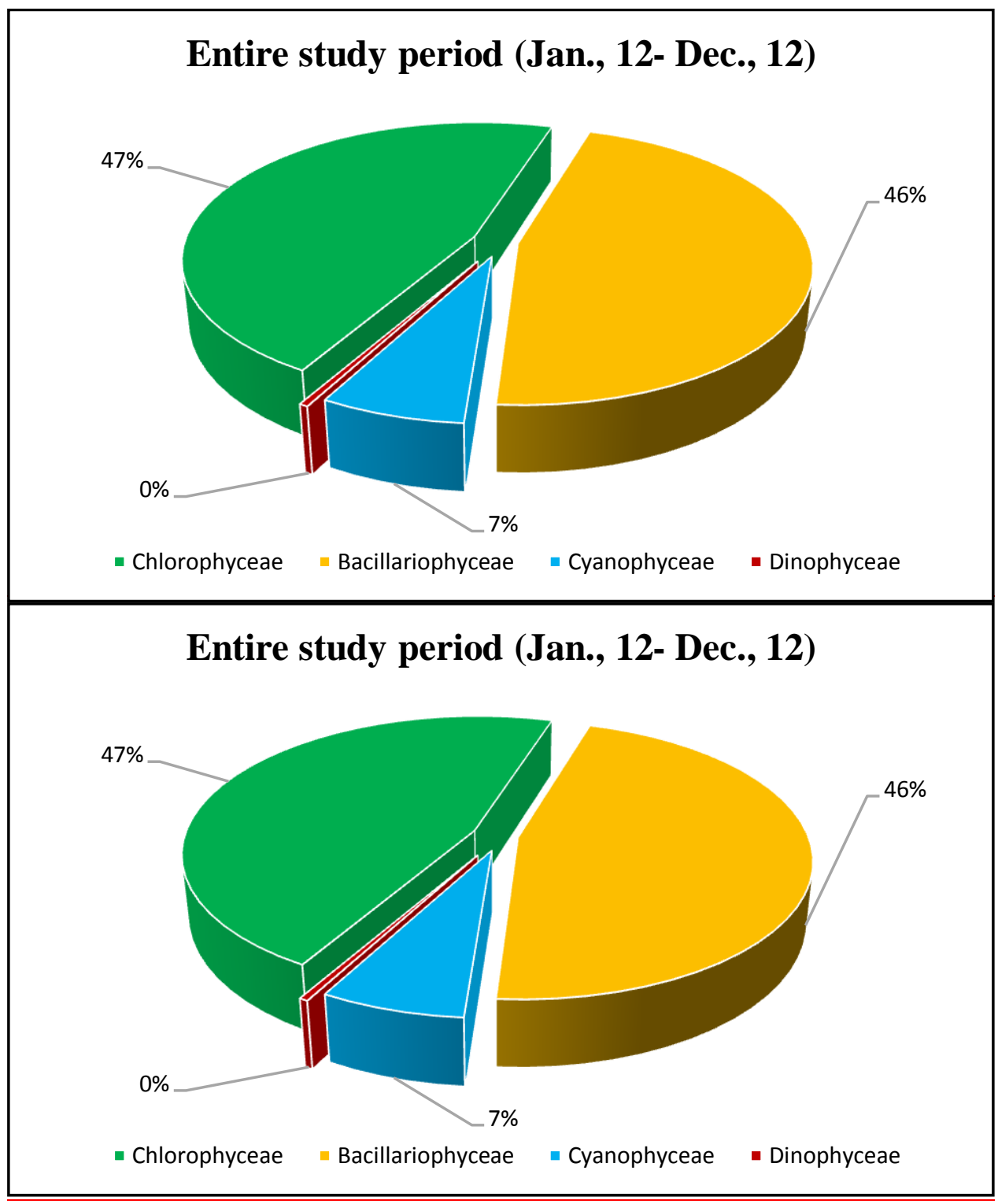

Fig.1.1:- Comparison of percent composition of various groups of phytoplankton in terms of density during entire study period i.e. Jan., 2012 to Dec., 2012 


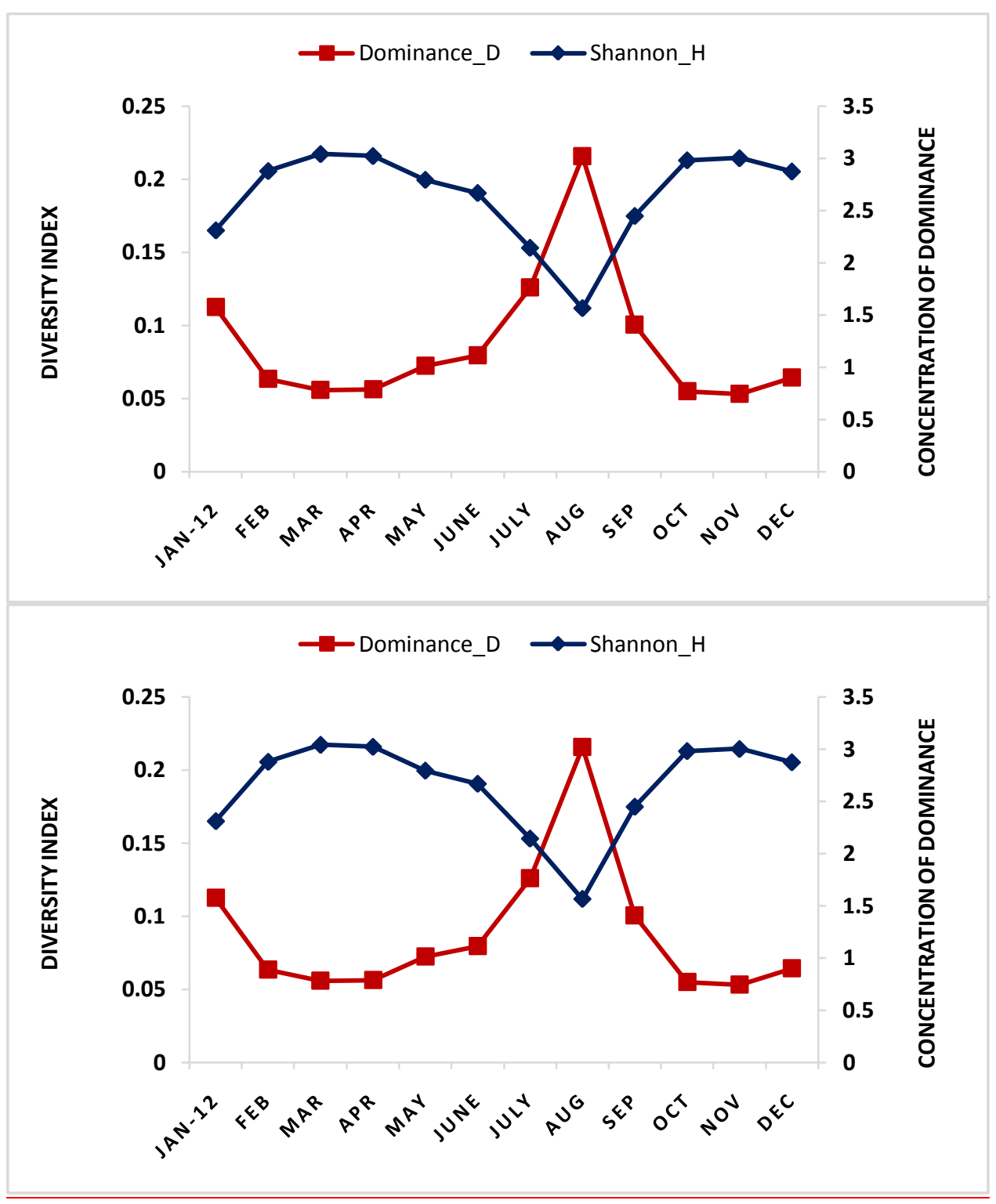

Fig. 1.2:-Seasonal variations in Shannon-Weiner diversity index and concentration of dominance of phytoplankton in Western Ramganga River from Jan., 2012 to Dec., 2012.

\section{References:-}

1. APHA, (1999); Standard Methods for the Examination of Water and Waste water. American Public Health Association and water pollution control federation; 20th ed., Washington: APHA).

2. Desai, S.R., SubashChandran, M.D. and Ramachandran, I.V. (2008); Phytoplankton diversity in Sharavati River basin central Western Ghat, The Icfai University Journal of soil and water science, Vol I: 1.

3. Devika, R., Rajendran, A. and Selvapathy, P. (2006); Variation studies on the physico-chemical and biological characteristics at different depths in model waste stabilsation tank. Pollut. Res., 24: 771-774.

4. Edmondson, W.T. (1959); Fresh water Biology. John Wiley and Sons. New York.

5. Essien-Ibok, M.A. and Umoh, I.A. (2013); Seasonal association of physico-chemical parameters and phytoplankton density in Mbo River, Akwalbom State, Nigeria IACSIT International Journal of Engineering and Technology, 5(1): 529.

6. Fitter, R. and Manuel (1986); Freshwater life of Britain and North West Europe. William Collins Sons \& Co. Ltd. London. 
7. Khan, Amir and Ishaq, Fouzia (2013); Comparative assessment of physico-chemical conditions and Plankton diversity of River Tons and Asan in Dehradun District of Uttarakhand. Advances in Applied Science Research, 4(2): 342-355.

8. Negi, R.K. and Rajput, Anjana (2013); Impact of Pulp and Paper Mill Effluents on Phytoplanktonic Community Structure in Ganga River at Bijnor (Up), India Journal of Entomology and Zoology Studies, 1(5): 70-73.

9. Panda, C.R., Palleyi, S. and Kar, R.N. (2011); Influence of Water quality on the biodiversity of phytoplankton in Dhamra River Estuary of Odisha Coast, Bay of Bengal J. Appl. Sci. Environ. Manage, 15(1): 69-74.

10. Rajagopal, T., Thangamani A. and Archunan, G. (2010); Comparison of physico- chemical parameters and phytoplankton species diversity of two perennial ponds in Sattur area, Tamil Nadu, 31(5): 787-794.

11. Ramesha, M.M. and Sophia, S. (2013); Species composition and diversity of Plankton in the River Seeta at Seetanadi, the Western Ghats, India. Advanced Bio. Tech., 12(8): 2319-6750.

12. Shekhar, R.T., Kiran, B.R., Puttaiah, E.T., Shivaraj, Y. and Mahadevan, K.M. (2008); Phytoplankton as index of water quality with reference to industrial pollution. J. Environ. Biol., 29: 233-236.

13. Verma, Rakesh (2013); Current status of physico-chemical characteristics and biological factor of W. Ramganga River in Kumaun Himalaya, India. Int. J. Curr. Microbiol. App. Sci., 2(8): 114-123.

14. Welch, P.S. (1952); Limnological Mc Grawl Hill Book Company Inc. New York. 